\title{
Achieving Transparency in Implementing Abortion Laws
}

\author{
Bernard Dickens, Rebecca Cook and Joanna Erdman
}

\author{
Version Publisher's Version \\ Citation Bernard Dickens, Rebecca .J. Cook \& J.N. Erdman, "Achieving \\ (published version) Transparency in Implementing Abortion Laws" (2007) 99 International \\ Journal of Gynecology and Obstetrics 157.
}

\section{Copyright/License

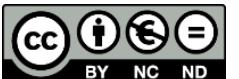 \\ This work is licensed under the Creative Commons \\ Attribution-NonCommercial-NoDerivatives 4.0 \\ International License. To view a copy of this license, visit http://creativecommons.org/licenses/by-nc-nd/4.0/.}

How to cite TSpace items

Always cite the published version, so the author(s) will receive recognition through services that track citation counts, e.g. Scopus. If you need to cite the page number of the author manuscript from TSpace because you cannot access the published version, then cite the TSpace version in addition to the published version using the permanent URI (handle) found on the record page.

This article was made openly accessible by $U$ of $T$ Faculty. Please tell us how this access benefits you. Your story matters. 


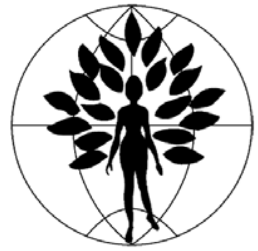

\title{
Achieving transparency in implementing abortion laws
}

\author{
R.J. Cook ${ }^{a}$, J.N. Erdman ${ }^{b}$, B.M. Dickens ${ }^{a, *}$ \\ ${ }^{a}$ Faculty of Law, Faculty of Medicine and Joint Centre for Bioethics, University of Toronto, Toronto, Ontario, Canada \\ ${ }^{\mathrm{b}}$ Health Equity and Law Clinic, International Reproductive and Sexual Health Law Programme, Faculty of Law, \\ University of Toronto, Toronto, Ontario, Canada
}

\section{KEYWORDS \\ Abortion; \\ Duties to clarify law; Implementing abortion law; Judicial clarification of law; Lawful abortion; Legal transparency; States' clarification of law}

\begin{abstract}
National and international courts and tribunals are increasingly ruling that although states may aim to deter unlawful abortion by criminal penalties, they bear a parallel duty to inform physicians and patients of when abortion is lawful. The fear is that women are unjustly denied safe medical procedures to which they are legally entitled, because without such information physicians are deterred from involvement. With particular attention to the European Court of Human Rights, the UN Human Rights Committee, the Constitutional Court of Colombia, the Northern Ireland Court of Appeal, and the US Supreme Court, decisions are explained that show the responsibility of states to make rights to legal abortion transparent. Litigants are persuading judges to apply rights to reproductive health and human rights to require states' explanations of when abortion is lawful, and governments are increasingly inspired to publicize regulations or guidelines on when abortion will attract neither police nor prosecutors' scrutiny.

(c) 2007 International Federation of Gynecology and Obstetrics. Published by Elsevier Ireland Ltd. All rights reserved.
\end{abstract}

\section{Introduction}

Initiatives in several countries address and remedy uncertainties in how abortion laws are to be implemented. Legislation usually sets penalties for unlawful abortion, but fails to distinguish how increasingly liberalized grounds for lawful abortion are established, so deterring medical practitioners from promptly delivering the care to which women are legally entitled. Some government agencies are respond-

* Corresponding author. 84 Queen's Park, Toronto, Ontario, Canada M5S 2C5. Tel.: +1 416978 4849; fax: +1 4169787899.

E-mail address: bernard.dickens@utoronto.ca (B.M. Dickens). ing to this concern by specifying tests physicians may apply to ensure that they act within the law and will not be subject to judicial proceedings.

For instance, Article 86 of the Criminal Code of Argentina renders abortion lawful when the health of the pregnant woman is at stake, or pregnancy is due to rape. In February 2007, a case of a 14-year-old girl raped by her stepfather had to reach the Court of Appeal of the City of Mar del Plata before her therapeutic abortion could be undertaken [1]. Consequently, in March 2007, the Minister of Health of the Province of Buenos Aires created a program to end uncertainties physicians face when considering abortions lawful under Article 86, and to prevent their decisions being subject to judicial challenge [2]. The program followed the 
Court of Appeal's decision on criteria of danger to physical or mental health, and of sexual assault, that protect physicians who reach abortion decisions with patients. The Social Action and Health Committee of the National House of Representatives in Argentina had filed a report favoring this development in June 2005 [3].

These initiatives reflect and anticipate requirements of leading courts that laws or governments authoritatively specify the circumstances in which physicians will be secure from police action and prosecutors' opposition in acceding to their patients' requests for legal abortions. Several recent decisions of international human rights courts and commissions, constitutional and national supreme and comparable courts address governmental duties regarding implementation of abortion laws.

\section{European Court of Human Rights}

The case of Tysiac against Poland [4] involved a woman suffering from severe myopia who was bringing up two small children alone, and feared on diagnosis of her third pregnancy that the stress would further harm her sight and render her almost blind. Three ophthalmologists agreed that pathological changes in her retina were such that pregnancy and delivery constituted a risk to her eyesight, but refused the request to certify that abortion was indicated, and recommended only avoidance of exertion and postnatal sterilization. The Criminal Code of Poland renders termination of pregnancy imprisonable, but the Family Planning (Protection of the Human Foetus and Conditions Permitting Pregnancy Termination) Act of 1993, as amended, provides in Section 4(a) (1) (1) that a physician may undertake abortion where "pregnancy endangers the mother's life or health." However, the specialists refused to issue certificates on the ground that, although the retina might detach itself as a result of pregnancy, it was not certain that it would.

Subsequently, a general practitioner certified that the third pregnancy presented the risk of rupture of the uterus, since the two previous deliveries were cesarean, and that the physical strain of pregnancy and raising two small children alone would seriously aggravate her visual disability. A 1997 ordinance of the Ministry of Health required that certification of abortion based on danger to life or health be attested by a consultant specialist in the medical field relevant to the woman's condition. However, the head of the Clinic of Gynaecology and Obstetrics in Warsaw, to which the woman was assigned, declined on a superficial examination to attest the general practitioner's certification. After the woman's cesarean delivery, her eyesight deteriorated badly, and she faced the risk of blindness with no prospects of surgical correction.

Failing to obtain any redress in Polish judicial or administrative tribunals, she applied to the European Court of Human Rights, which found the claim admissible. The key issue concerned violation of Article 8(1) of the European Convention for the Protection of Human Rights and Fundamental Freedoms, which provides that "Everyone has the right to respect for his private... life." The Court noted that "private life" is a broad term, encompassing physical and psychological integrity, that a woman's decision to resort to lawful abortion is private, and that Poland had violated
Article 8(1). Drawing on its own earlier judgments, the Court observed in para. 110 of its judgment that it had previously ruled that:

there may... be positive obligations [on a state] inherent in an effective "respect" for private life. These obligations may involve the adoption of measures designed to secure respect for private life even in the sphere of relations between individuals, including both the provision of a regulatory framework of adjudicatory and enforcement machinery protecting individuals' rights and implementation, where appropriate, of specific measures [5].

Poland was found in violation of women's rights to abortion that was lawful under its legislation, because it had failed to create a regulatory framework under which women would know how to access procedures to which they are entitled, to be involved in the decision-making processes affecting them, and to obtain independent review of unfavorable decisions.

The Court reiterated in para. 113 that:

The Convention [on Human Rights] is intended to guarantee not rights that are theoretical or illusory but rights that are practical and effective...

That is, Poland is obligated to create means to ensure that women's interests in lawful abortion procedures are served by regulations that achieve their timely, safe, and voluntary access in conditions of privacy and respect.

The Court further noted, in para. 116 of its judgment that:

the legal prohibition on abortion, taken together with the risk of their incurring criminal responsibility under... the Criminal Code, can well have a chilling effect on doctors when deciding whether the requirements of legal abortion are met in an individual case. The provisions regulating the availability of lawful abortion should be formulated in such a way as to alleviate this effect. Once the legislature decides to allow abortion, it must not structure its legal framework in a way which would limit real possibilities to obtain it.

This observation addresses the long history of abortion legislation that includes conditions that deliberately or incidentally obstruct or deny practical access [6]. In para. 124 , the Court based its condemnation on the ground that:

it has not been demonstrated that Polish law... contained any effective mechanisms capable of determining whether the conditions for obtaining a lawful abortion had been met... As a result, the applicant suffered severe distress and anguish when contemplating the possible negative consequences of her pregnancy and upcoming delivery for her health.

\section{UN Human Rights Committee}

The case known as KL against Peru [7] arose under the Optional Protocol to the International Covenant on Civil and Political Rights. Peru had ratified the protocol, allowing its citizens to proceed against it before the Committee, but failed to cooperate in these proceedings, to contest evidence submitted by $\mathrm{KL}$, and to defend actions for which the State was responsible. 
KL became pregnant when aged 17, and her fetus was found anencephalic. A gynecologist/obstetrician at the Archbishop Loayza National Hospital in Lima wrote that continuation of pregnancy posed a risk to her life. He recommended abortion, which Peruvian law allows on this indication, and $\mathrm{KL}$ and her mother approved. However, the abortion required authorization from the hospital's director, which he refused on the claim, unsupported by a legal opinion, that the procedure was unlawful unless it was the only way to save KL's life or avoid serious permanent damage to her health. KL delivered a baby that survived for four days, and was required to undertake breast-feeding. KL suffered consequent deep depression, which was psychiatrically found to have a severe impact on her development and future mental health.

The Committee considered the State's conduct according to provisions of the Covenant, and found Peru in violation of Article 7, which forbids cruel, inhuman or degrading treatment. Such treatment consisted in the director of the State's hospital ignoring the risk expressed in the letter of his hospital's gynecologist/obstetrician, and compelling KL to endure the distress of seeing her baby's gross deformities and to breastfeed knowing that the baby was soon to die. Further, a violation was found of Article 17, which prohibits arbitrary or unlawful interference with privacy. Interference consisted in the director of the State hospital denying $\mathrm{KL}$ a procedure to which she was legally entitled, and her compliance with her gynecologist's recommendation.

Reinforcing these violations, the Committee found a violation of Covenant Article 24, in that the State did not afford $\mathrm{KL}$ the special care due to her as a minor, particularly the medical and psychological support necessary in her pregnancy and its compelled continuation. In conjunction with other violations, the Committee also found a transcending violation of Article 2, which requires States "to take the necessary steps... to adopt such legislative or other measures as may be necessary to give effect to the rights recognized in the present Covenant." The Article also requires States to ensure effective remedies for violations, including judicial recourse. KL lacked an adequate legal remedy in Peru for the State's violations of her rights, and adequate preventative measures, including adequate guidance to the hospital director and others of physical and mental health indications for lawful abortion [8].

\section{Constitutional Court of Colombia}

The Penal Code of Colombia prohibits abortion in absolute terms, although when the Code provisions were challenged as a violation of the 1991 Constitution of Colombia, the Attorney General defended the Code as allowing a woman and physician to plead necessity to preserve the woman's life [9]. Beyond a traditionally narrow approach to the law, however, the Attorney General took the enlightened view of measuring the punitive Code against the more liberal values of the Colombian Constitution, which includes the commitment to comply with the country's international responsibilities under human rights treaties.

The proceedings by five citizens of Colombia for a declaration of unconstitutionality were potentially adversarial, but for the government, the Attorney General agreed with the plaintiffs that voluntary termination of pregnancy should not be a crime when conception was not consented to by the pregnant woman, such as when imposed by rape, when the pregnancy presented serious risk to her life or physical or mental health, or when medical certification shows serious illness or malformation that makes the fetus nonviable.

The Attorney General argued that analysis of the principle of protection of human dignity contained in the Constitution, and of the rights to life and liberty embodied in this principle, renders criminalization of abortion in the above circumstances an irrational and disproportionate punishment for women, which violates their rights, exceeds the legislature's discretion over criminal matters, and is unconstitutional. The Court's judgment of 2006 reflected this approach, referring to the range of international human rights treaties Colombia has ratified. It gave particular attention to women's rights, noting that:

The 1991 Constitution expressly sets out the goal of recognizing and enhancing the rights of women, as well as of reinforcing these rights by protecting them in an effective and decisive manner. Thus, women are now entitled to special constitutional protection and their rights must be recognized and protected by government authorities, including those within the legal system, without exception.... [10]

The Court addressed obligations under both the Convention on the Elimination of All Forms of Discrimination against Women, and the concept of reproductive health and associated rights developed through the Programme of Action of the 1994 UN International (Cairo) Conference on Population and Development, and the Beijing Platform of the 1995 Fourth World Conference on Women. The Court went back to the 1968 First World Conference on Human Rights, held in Teheran where, for the first time, the basic human right of parents "to determine freely and responsibly the number and spacing of their children" was recognized [10]. Rights of reproductive choice were further considered in the context of the American Convention on Human Rights "Pact of San José, Costa Rica," in force since 1978, and the evolving jurisprudence of the Inter-American Court of Human Rights.

Expansive though the Court was on women's rights, and recognizing that "[t]he legislature must not impose the role of procreator on a woman against her will," [11] the declaration requested confined the Court to stating limits on the role of criminal law in regulating abortion. The Court could not direct the legislature on positive measures it should enact to ensure women's access to lawful procedures, but could only review action after it occurs, since "[t]he intervention of the constitutional judge comes... only in order to examine whether the legislature has exercised its powers within the limits of its discretion" [12].

\section{Northern Ireland Court of Appeal}

In 2004, the Court of Appeal of Northern Ireland, the highest court in the province, decided a case in which the Family Planning Association of Northern Ireland sued the provincial health ministry for a declaration that the ministry's failure to clarify and publicize women's rights to access abortion services under prevailing law violated the ministry's legal 
duties [13]. The declaration was sought since the liberalizing UK Abortion Act 1967 is inapplicable in Northern Ireland, and each year an estimated 2000 women from the province go to Britain for abortions that are lawful there, each at a cost of between $£ 500$ and $£ 1200$. Women unable to afford this cost, or to travel, must continue gestation, or risk unskilled abortion, even when prevailing law in Northern Ireland allows physicians to act, if not deterred by the fear of prosecution and up to life imprisonment.

The trial judge explained that, under prevailing law, abortion is lawful in Northern Ireland when a physician, in good faith, finds that continuation of pregnancy would seriously endanger a woman's life or her physical or mental health, but refused the declaration on the ground that his ruling provided all necessary clarification. The Court of Appeal's three judges granted the declaration, since the ministry was under affirmative duties realistically to assess the need for abortion services, including for women returning from elsewhere following abortions, and publicize how the ministry proposed to meet that need [14]. Physicians' apprehension of a law expressed only prohibitively, with liability to a ferocious penalty, needed to be redressed by assurances of what procedures would attract neither police scrutiny nor penalty.

The Court of Appeal formally required the ministry only to assess the evidence of women's need for services, and propose means to assure appropriate medical care in Northern Ireland with privacy and dignity. However, the judges offered guidance on what types of regulations would be appropriate, and observed that inadequate ministry proposals would be open to further judicial review.

\section{United States Supreme Court}

The US Supreme Court decision of April 2007 in Gonzales vs Carhart [15] may be more significant for what it foreshadows than for its direct effect on abortion services. In 2000, a differently composed US Supreme Court held legislation from Nebraska on late-term abortions of pre-viable fetuses unconstitutional, on grounds of vagueness or over-inclusiveness, and absence of an exception to preserve women's health [16]. The 2007 case concerned an almost identical federal Act, named in non-medical language the Partial-Birth Abortion Ban Act, of 2003. The Court's five-to-four majority found this Act more precise, however, and ruled it constitutional, although it again included no exception permitting the otherwise prohibited procedure when physicians find it indicated in their patients' health interests.

Membership of the US Supreme Court results from overtly political decisions. For the executive branch of government Presidents offer nominees, and for the legislative branch the Senate Judiciary Committee recommends approval or rejection. When appointed, the judges (called "justices") do not apply the collegial approach of other Supreme Courts, in which in subsequent cases minority judges defer to the majority [17], but maintain individualistic approaches. For instance, the three justices dissenting from the majority six in the landmark 1973 abortion decision in Roe vs Wade [18] contributed to polarization on the issue, in that those favoring their approach hoped that their numbers could be raised to a majority by judicial replacements of the prevailing justices. The issue has so permeated US politics and public life that potential judicial nominees' perceived position on abortion has become a litmus test of their prospects.

Political dominance of this single issue has discredited the international standing of US judgments. The 1973 decision was widely respected in other countries, and influenced decisions of other leading courts, such as in Canada [19]. However, more recently, courts outside the country, such as the English High Court [20], have found US abortion decisions irrelevant, due to their peculiar preoccupation with this issue and its colonizing effect on other legal concerns, and US non-membership of leading international human rights treaty regimes.

It remains unclear how far the 2007 decision will reach. The federal Act bans the procedure variously medically described as "intact dilation and evacuation" (intact D\&E), "dilation and extraction" (D\&X), and "intact D\&X." The Court recognized that the Act does not cover a procedure in which a fetus is intended to be removed in parts, so that it affects not accidental intact $D \& E$, nor the number of abortions themselves, but only those by surgical techniques designed to achieve abortion by partial delivery of a living fetus. The Court found that the legislature could in principle constitutionally ban such procedures.

The Court accepted its previous rulings that abortion prohibitions are unconstitutional if they involve an "undue burden" on women seeking abortions before fetal viability [21]. The Court found that nothing in the language of the 2003 Act imposed such a burden. It discounted medical evidence that intact D\&E is safer for women's health because it decreases risks of cervical laceration and uterine perforation, of removing bony fetal fragments, and of leaving fetal parts in the uterus. However, it recognized that actual evidence could render application of the Act unconstitutional, since "the proper manner to protect the health of the woman [is] if it can be shown that in discrete and welldefined instances a particular condition has [occurred] or is likely to occur in which the procedure prohibited by the Act must be used" [22]. That is, the Act remains open to constitutional challenge, but only after the facts of particular instances have shown application of the Act to jeopardize women's health.

\section{Conclusion}

The US Supreme Court decision of April 2007, upholding restrictive legislation, runs counter to the general thrust of judicial decisions and governmental regulations, which have opened lawful pathways for access to medically indicated abortion. The concept of reproductive health and of associated reproductive rights, together with the need to protect women's health against the scourge of unskilled abortion, has taken effect in some countries to inspire public and/or private initiatives to secure access to lawful medical services. For instance, Colombia issued standards for abortion practice in December 2006 in compliance with its Constitutional Court ruling [23]. Following the judgment in Northern Ireland, the Ministry established a Working Group to develop guidance on the abortion law and identify good medical practice. Draft guidelines were distributed for consultation in January 2007. 
The Ministry then plans to issue final guidance to the health professions, and informational leaflets to the general public.

In Brazil, an association of health professionals has taken judicial proceedings [24] to resolve the ambiguity of whether anencephalic pregnancies may lawfully be terminated, since the criminal law allows no indication of gross fetal deformity. Physicians will not undertake termination without judicial authorization, which some judges have granted but others have denied. To avoid the delay, stress, expense and uncertainty of taking each incident to court, judicial clarification is requested [25].

As judges become increasingly responsive to women's claims to reproductive health and rights, recognized in national and international human rights principles, citizens may take initiatives to seek clarification of the grounds and procedures for access to lawful abortion services. As governments that respect the rule of law in practice, not only in their rhetoric, recognize this at national and international levels, they take initiatives to formulate and implement practices that achieve transparency in rights to request and undertake lawful abortion.

\section{References}

[1] O., M. v. S/victima de abuso sexual. Decision of February 21, 2007, Civil and Commercial Court of Appeal, Mar del Plata.

[2] Resolution 304/2007, Provincial Health Program for the Prevention of Family and Sexual Violence and for the Assistance of Victims.

[3] Report (in Spanish) on the relevant sexual and reproductive health legislation in Argentina and in the City of Buenos Aires, at http://defensoria.gov.ar/areastematicas/doc/salud02.doc.

[4] Tysiac v. Poland, Application No. 5410/03, European Court of Human Rights, Judgment 20 March 2007.

[5] $X$ and $Y ~ v$. the Netherlands, judgment of 26 March 1985, Series A no 91 , p.11, para 23.

[6] Hansson D, Russell DEH. Made to fail: the mythical option of legal abortion for survivors of rape and incest. S Afr J Hum Rights 1993;9:500-24.

[7] KL v. Peru, Communication No. 1153/2003, UN Doc CCPR/C/85/ D/1153/2003. Human Rights Committee, 85th session; 2005.
[8] Cook RJ, Ortega-Ortiz A, Romans S, Ross LE. Legal abortion for mental health indications. Int J Gynecol Obstet 2006;95: 185-90.

[9] Decision C-355/06, May 10, 2006 (Constitutional Court of Colombia).

[10] Decision C-355/06, May 10, 2006 (Constitutional Court of Colombia, Section 6.

[11] Decision C-355, May 10, 2006 (Constitutional Court of Colombia) Section 8.1.

[12] Decision C-355, May 10, 2006 (Constitutional Court of Colombia) Section 10.1.

[13] Cook RJ, Dickens BM, Erdman JN. Emergency contraception, abortion and evidence based law. Int J Gynecol Obstet 2006;93: 191-7.

[14] Family Planning Association of Northern Ireland v. Minister for Health, Social Services and Public Safety, [2005] Northern Ireland Law Reports 188 (Court of Appeal).

[15] Gonzales v. Carhart, 550 United States Reports, [page pending] (2007) (US Supreme Court).

[16] Stenberg v. Carhart, 530 United States Reports 914 (2000) (US Supreme Court).

[17] Wilson B. Decision-making in the Supreme Court [of Canada]. Univ Tor Law J 1986;36:227-48.

[18] Roe v. Wade, 410 United States Reports 113 (1973) (US Supreme Court).

[19] Morgentaler v. The Queen (1988), 44 Dominion Law Reports (4th) 385 (Supreme Court of Canada).

[20] R. on the Application of Axon v. Secretary of State for Health, (2006) England and Wales High Court 37 (Administrative Court) Case No. CO/5307/2004.

[21] Planned Parenthood of Southeastern Pennsylvania v. Casey, 505 United States Reports 833 (1992) (US Supreme Court).

[22] Gonzales v. Carhart, 550 United States Reports, [page pending] (2007) (US Supreme Court), Section 5.

[23] Ministerio de la Protección Social. Resolución No. 4905 de 2006. Por la cual se adopta la Norma Técnica para la atención de la Interrupción Voluntaria del Embarazo - IVE.

[24] National Confederation of Healthcare Workers' petition, ADPF No. 54-8/DF 2004, 27 October 2004. (Supreme Court of Brazil).

[25] Diniz D. Antecipação terapêutica do parto: uma releitura bioética do aborto por anomalia fetal no Brazil. In: Diniz D, Ribeiro DC, editors. Aborto por Anomalia Fetal. Brazilia: Debora Diniz; 2003. p. 21-92. 